мобільності (є необхідним у процесі формування проектно-конструкторської компетентності, тому що майбутній інженер повинен не лише оволодіти теоретичними та практичними знаннями, а й розвивати свій інтелект, творчі здібності, що $є$ необхідним для майбутньої діяльності).

Отже, комплексне застосування компетентнісного, системного та особистісно зорієнтованого підходів забезпечить не лише ефективне засвоєння практичного та теоретичного матеріалу, а й активізує інтелектуальний та вольовий потенціал майбутнього інженера. Єдність загально дидактичних та специфічних принципів сприятиме розвитку особистості та іiі подальшому професійному становленню. Це забезпечить успішне формування ПКК майбутнього інженера у процесі вивчення графічних дисциплін.

\title{
Література
}

1. Методика навчання української мови в середніх освітніх закладах/ 3. П. Бакум, І. В.Гайдаєнко, О. М. Горошкіна та ін. / за заг. ред. М. І. Пентилюк. - К. : Ленвіт, 2005. - 400 с. 2. Грачева С. В. Совершенствование процесса обучения начертательной геометрии с использованием учебного пособия развивающего типа : дис. канд. пед. наук : спец. 13.00.08 / Светлана Владимировна Грачева- М., 2006. 234 с. 3. Овчарук О. В. Компетентності як ключ до оновлення змісту освіти / О. В. Овчарук // Стратегія реформування освіти в Україні. - К., 2003. - С. 13-41. 4. Пузанкова А. Б. Формирование профессиональных инженерно-графических компетенций студентов в процессе обучения компьютерной графике : дис. канд. пед. наук: спец. 13.00.08 / Александра Борисовна Пузанкова - М., 2012. - 190 с. 5. Русинова Л. П. Системный подход в изучении начертательной геометрии / Л. П. Русинова // Молодой ученый. - М., 2010 - № 9.- С. 268-273. 6. Фурман А. В. Повышение эффективности графической подготовки школьников (на материале предметов черчения и трудового обучения 4-8 классов) : дис. канд. пед. наук: спец. 13.00.01 / Анатолий Васильевич Фурман. - К., 1984. - 210 с.

\section{ЧИННИКИ ФОРМУВАННЯ КОНКУРЕНТОСПРОМОЖНОСТІ ВНЗ}

Цебро Я. І. Чинники формування конкурентоспроможності ВНЗ.

У статті висвітлено основні проблеми забезпечення конкурентоспроможності закладів освіти, 3 урахуванням сьогоденних реалій. Охарактеризовано сутність поняття «конкурентоспроможність ВНЗ» та визначено основні чинники іiі формування. Обгрунтовано значимість кожного 3 чинників у процесі підвищення конкурентоспроможності.

Ключові слова: конкуренція, конкурентоспроможність, конкурентоспроможність ВН3, фактор, показники.

Цебро Я. И. Факторы формирования конкурентоспособности вузов

В статье отражены основные проблемы обеспечения конкурентоспособности учебных заведений, учитывая настоящем реалии. Охарактеризована сущность понятия «конкурентоспособность вуза» и определены основные факторы ее формирования. Обоснована значимость каждого из них в процессе повышения конкурентоспособности.

Ключевые слова: конкуренция, конкурентоспособность, конкурентоспособность вузов, фактор, показатели. 
Tsebro Y. I. Factors of forming of competitiveness in institutes of higher.

In the article basic problems of providing competitiveness of educational establishments, taking into account today's reality, are reflected. In this connection, essence of concept «competitiveness of higher educational establishment» is described and the basic factors of its forming are defined. Meaningfulness of each of them in the process of competitiveness increase is grounded.

Key words: competition, competitiveness, competitiveness of institutes of higher, factor, indexes.

Реформування системи освіти, яка є одним з визначальних чинників становлення України як сучасної демократичної європейської держави, іiї адаптація до умов сьогодення $\epsilon$ актуальним завданням у реалізації стратегічних цілей держави в напрямі забезпечення високого рівня конкурентоспроможності економіки України, економічного зростання та сталого розвитку [1].

В умовах переходу освітньої діяльності до ринку відносини змагальності, що характерні для економіки, змінюються відносинами конкуренції, особливо між вищими навчальними закладами (ВНЗ). Це спонукає ВНЗ розвивати матеріальнотехнічну базу, підвищення якості викладання, що мобілізує заклад у ринкових умовах. Більшість населення прагне отримати вищу освіту, тому перед ним стає жорсткий відбір освітніх закладів, які прагнуть працювати на ринку, що у свою чергу, зумовило конкуренцію між ВН3 [2].

До основних причин загострення конкурентної ситуації на ринку освітніх послуг в Україні слід віднести: зростання кількості та ринкової частки недержавних освітніх закладів, які характеризуються більшою мобільністю, розвиненою матеріальнотехнічною базою, гнучкістю цінової політики; входження України до Європейського освітнього і наукового простору та, як наслідок, конкуренція із зарубіжними ВНЗ.

Досліджуючи проблему конкурентоспроможності ВНЗ, науковці підкреслюють, що ситуація на вітчизняному ринку освітніх послуг 3 кожним роком стає все більш напруженою, а система управління вищими навчальними закладами, зважаючи на іiі консервативність та залежність від бюджетного фінансування, є найбільш вразливою ланкою у практиці управління конкурентоспроможністю. Зазначене визначає актуальність проблеми формування та забезпечення конкурентоспроможності ВНЗ, дослідженню якої присвятили свої праці такі науковці, як: О. Белаш, І. Гараєв, В. Лазарев, І. Лошенюк, С. Мохначов, Н. Пащенко, Х. Фасхієв та ін. [1].

Mema cmammi- проаналізувати підходи науковців до визначення поняття конкурентоспроможності ВН3, а також чинників іiі формування та виокремити основні $з$ них.

Аналіз розроблених у науковій літературі підходів до визначення поняття конкурентоспроможності ВНЗ у системі умов та чинників іiї формування засвідчив, що в певних наукових колах конкурентоспроможність розглядається як комплексна характеристика вищого навчального закладу, що відображає його перевагу над конкурентами за системою визначальних показників- наукових, фінансовоекономічних, маркетингових, матеріально-технічних, кадрових i соціальнополітичних, а також здатність ВНЗ у визначений період часу та в умовах конкретного ринку до безкризового функціонування і своєчасної адаптації до умов зовнішнього середовища, що змінюються [3; 4; 5].

Аналіз літературних джерел дозволив виявити відсутність єдиного визначення поняття «конкурентоспроможність вищого навчального закладу», тому визначення 
терміну має важливе значення щодо отримання наукової позиції та практичного результату.

Так, Н. Пащенко визначив конкурентоспроможність ВНЗ як потенційні можливості з надання відповідного рівня освітніх послуг, що задовольняють потреби суспільства під час підготовки висококваліфікованих спеціалістів, а також необхідність розроблення, створення та реалізацію науково-методичної та науковотехнічної продукції як на сучасному етапі, так i в майбутньому [6]. Подане визначення спрямоване на перевагу соціальних інтересів, але не розкриває потенціалу самого вищого навчального закладу. Надання освітніх послуг не визначає достатній рівень конкурентоспроможності ВНЗ та здатності протистояти реальним конкурентам на ринку освіти.

Визначення І. Ромонової «конкурентоспроможність - це властивість вищого навчального закладу, яка визначає долю релевантного ринку освітніх послуг, що належать певному ВНЗ, та можливість протистояти перерозподілу ринку на користь інших суб'єктів» [7]. Недосконалість цього визначення залежить від показника економічної діяльності ВНЗ, що відображає його дійсний і перспективний стан на деяких сегментах ринку.

Р. Фатхутдінов зауважив, що конкурентоспроможність вищого навчального закладу це: «...1) підготовка спеціалістів, які у змозі вести конкуренту боротьбу на внутрішньому та зовнішньому ринку праці; 2)спроможність розробляти конкурентні інновації в області освіти; 3) уміння вести ефективну політику в усіх сферах своєї діяльності» [8].

У наукових працях автори намагаються розглядати конкурентоспроможність вищого навчального закладу як комплексну характеристику ВНЗ за зазначений період часу в умовах конкретного ринку, відображаючи перевагу над конкурентами, а також здатність ВНЗ до постійного функціонування і своєчасної адаптації до змін зовнішнього середовища.

Поруч 3 цим установлено, що освітні послуги мають значні відмінні особливості порівняно 3 товарами, а також більшістю пропонованих послуг. Визначені відмінності рекомендується використовувати під час формування конкурентних переваг вищих навчальних закладів на ринку освітніх послуг України [1].

Для цього необхідно встановити основні групи показників конкурентоспроможності освітніх послуг та визначити склад показників кожної групи.

Слід погодитись із пропозицією про поділ усіх показників, які характеризують конкурентоспроможність товару, на три групи [9]:

- показники корисності (якість, ефективність використання і т.д.);

- витрати споживачів (ціна споживання, зручність системи оплати);

- показники, які характеризують ефективність пропозиції.

Групу показників корисності освітніх послуг доцільно розбити ще на дві підгрупи.

Показники першої, так звані- нормативні, відображають принципову можливість реалізації послуг на конкретному ринку. Надання освітніх послуг уважається можливим, якщо всі іiї основні параметри задовольняють чинні норми та вимоги. Якщо хоча б один з параметрів не задовольнить цих вимог, освітню послугу слід уважати неконкурентоспроможною.

Друга підгрупа характеризує якість наданої освітньої послуги, можливість навчання без відриву від виробництва, вибір спеціальності, термін навчання та доступність освітньої послуги.

Під час визначення міри доступності певної освітньої послуги враховується 
різноманітність форм навчання у навчальному закладі, наявність філіалів i представництв, ступінь розвитку дистанційного навчання.

До другої групи показників конкурентоспроможності освітньої послуги відноситься ціна реалізації освітньої послуги та зручність системи оплати.

Окремо слід відмітити групу нетоварних факторів, які визначають рівень конкурентоспроможності освітніх послуг, та до яких слід віднести такі показники: довіра до навчального закладу (імідж), рівень рекламної діяльності та стимулювання збуту [9].

У контексті розгляду даного питання необхідно зазначити, що під час визначення інтегрального (загального) показника конкурентоспроможності ВНЗ ураховується низка чинників. Наприклад, Х. Фасхієв [10] нараховує 43 таких показники, які він поділяє на 5 груп:

1. Показники кваліфікаційного потенціалу навчального закладу.

2. Показники розвитку науково-методичної бази.

3. Показники забезпеченості матеріально-технічної бази.

4. Показники якості системи освіти.

5. Охоплення галузей підготовки фахівців.

Водночас серед такої різноманітності показників, немає жодного, який би характеризував рівень зайнятості випускників. Тому автори уважають, що для формування конкурентоспроможності ВНЗ необхідним $є$ також оцінка показників, які б визначали співвідношення між працевлаштованими й усіма випущеними студентами, між працевлаштованими за спеціальністю й усіма працевлаштованими випускниками, визначення показника, який характеризує середній термін працевлаштування випускників та ін.

У свою чергу одним із чинників формування конкурентоспроможності ВНЗ є його цінова політика. Для багатьох вищих навчальних закладів розглядуване питання не $є$ найбільш актуальним, насамперед для тих, які навчають велику кількість студентів за державним замовленням. Визначення плати за навчання на комерційній основі в них не базується на визначенні собівартості навчання студента за різними спеціальностями i формами, а встановлюється на основі середніх ринкових цін по регіону. [11] Натомість, приватні ВНЗ, прагнуть забезпечити певний рівень рентабельності власної освітньої діяльності і тому проводять більш виважену політику у сфері ціноутворення. Зауважимо, що низька ціна освітньої послуги може сформувати у свідомості споживача думку про низьку якість відповідної освітньої програми.

Переважно під час вибору ВНЗ і освітньої програми, на сучасному етапі, споживач звертає увагу на 2 основні показники: якість освітньої програми і витрати, що пов'язані 3 отриманням і експлуатацією освітньої послуги. Поєднуючи ці два чинники визначається сукупний корисний ефект для споживача послуги, максимізація якого забезпечує конкурентоспроможність як ВНЗ у цілому, так і його конкретної освітньої програми.

Елементом, який формує і підвищує конкурентоспроможність ВН3, є активізація збутової політики, а особливо сприяння просуванню випускників на ринку праці. Одним із елементів такого сприяння має стати створення у ВНЗ окремого підрозділу або хоча б визначення відповідальних осіб, які б накопичували відомості про поточні потреби на ринку праці, укладали б договори на проходження практики 3 можливим подальшим працевлаштуванням студента на підприємстві, допомагали б просуванню на ринок праці тих, хто закінчив навчання і всебічно сприяли б у пошуку роботи студентів старших курсів, які прагнуть поєднувати навчання і практичну діяльність [12].

У сучасних умовах важливе значення повинно відводитися фінансово-економічній 
складовій, зважаючи на низку чинників, основними з яких є: трансформаційні процеси, які відбуваються в системі сучасної освіти; скорочення бюджетного фінансування вищої освіти, що вимагає від ВНЗ постійного пошуку інших джерел залучення фінансових ресурсів для свого стабільного розвитку і $\epsilon$ визначальною умовою високого рівня конкурентоспроможності. Зазначимо, що якість та конкурентоспроможність освітніх послуг, забезпечення ефективності реформ у вищій школі вимагає достатності обсягів фінансування, а також залежить від оптимальності складу i структури джерел фінансування, форм та методів, які при цьому використовуються. Проте домінуючим джерелом нині залишаються кошти державного і місцевих бюджетів, оскільки саме державі належить пріоритет у формуванні, реалізації та модернізації освітньої політики відповідно до вимог сучасності.

Наголосимо на тому, що брак фінансування системи освіти викликає безліч не лише економічних, а й соціальних проблем. До таких проблем можна віднести: заборгованість по соціальних виплатах та комунальних послугах, ослабленість системи державного кредитування студентів, припинення фінансування програм покращення житлових умов науково-педагогічних працівників, недостатній обсяг фінансування наукової галузі, гальмування інноваційних програм розвитку освітньої системи. Крім того, необхідність збереження та розвитку матеріальної та навчальнометодичної бази зумовлює залежність навчальних закладів від коштів, які надходять як плата за навчання студентів-контрактників, що негативно позначається на якості підготовки фахівців та, як наслідок, конкурентоспроможності ВНЗ [13].

3 огляду на зазначене диверсифікація джерел фінансування освіти (залучення коштів студентів, запровадження освітнього кредитування, відкриття програм платної додаткової професійної освіти, проведення наукових досліджень на замовлення та ін.) $\epsilon$ одним із способів зменшення ресурсної залежності ВНЗ від держави. Ця проблема особливо загострилася внаслідок фінансово-економічної кризи, створюючи загрозу розвитку вищої освіти в Україні: з одного боку, скоротилися можливості бюджетного фінансування ВНЗ та, як наслідок, зменшення рівня заробітної плати професорськовикладацького складу, зменшення видатків на наукові дослідження, призупинення бюджетного фінансування пільгових кредитів на будівництво житла для науковопедагогічного та педагогічного персоналу; 3 іншого,- зросла частка коштів спеціального фонду, зароблених власне державними вищими навчальними закладами [14].

Іншим важливим індикатором розвитку освітньої системи та забезпечення іiі конкурентоспроможності $є$ динаміка показника інвестицій в освітню сферу, особливо зважаючи на те, що Україна обрала модель розвитку економіки, заснованої на знаннях.

Важливе місце серед джерел фінансування ВНЗ України різних форм власності займає цільове фінансування міжнародних організацій та оплата за навчання іноземних студентів (в Україні вищу освіту здобувають понад 27 тис. студентів із більше ніж 110 країн світу). У рамках програми Європейського союзу ТЕМПУС реалізовано 126 проектів iз загальним бюджетом понад 27 млн. євро [15].

Результатом співпраці вітчизняних ВНЗ з потенційними роботодавцями та іноземними вищими навчальними закладами $\epsilon$ значне підвищення якості освітніх послуг та залучення додаткових фінансових ресурсів, що робить вітчизняні ВНЗ більш конкурентоспроможними не тільки на внутрішньому ринку освітніх послуг, але й на зовнішньому, підвищує їх потенціал.

Отже, підсумовуючи все вище викладене, можна констатувати, що всі перераховані чинники $є$ важливими для формування конкурентоспроможності ВНЗ. 
Водночас нині більшість ВНЗ розглядають як основний чинник формування конкурентоспроможності лише якість освітніх послуг, що $є$ помилковим, оскільки в період загострення конкурентної боротьби та утримання конкурентних позицій на ринку вищим навчальним закладам необхідно проводити активну комунікаційну, цінову та збутову політику, що в подальшому дозволить сформувати і підвищити імідж ВНЗ і, як наслідок, його конкурентоспроможність.

\section{Література}

1. Андреева О. Отличительные черты, определяющие конкурентоспособность ВУЗов // [Електронний ресурс]. - Режим доступу : http:/www.megaportnn.ru/content/articles/19157/ 2. Буцька О. Ю. Джерела фінансування вищих навчальних закладів // О. Ю. Буцька // [Електронний ресурс]. - Режим доступу : http://www.sworld.com.ua/ 3. Іванов Ю. Конкурентоспроможність закладів вищої освіти споживчої кооперації на ринку освітніх послуг України/ Ю. Іванов. - Українська кооперація. - № 4. - 2011. // [Електронний ресурс]. - Режим доступу: http://www.ukrcoopjournal.com.ua/num/ivanov.htm 4. Інструменти формування конкурентоспроможності ВНЗ // [Електронний ресурс].- Режим доступу: http://referatcentral.org.ua/pedagogy_load.php?id $=2865$ 5. Карпюк О. А. Проблеми оцінки конкурентоспроможності освітніх послуг / О. А. Карпюк. // Економіка. Управління. Інновації. - 2009. - № 2. - [Електронний pecypc]. - Режим доступу: http://nbuv.gov.ua/j-pdf/eui_2009_2_18.pdf 6. Кравченко К. В. Управління конкурентоспроможністю вищого навчального закладу// [Електронний pecypc]. - Режим доступу: irbis-nbuv.gov.ua/.../cgiirbis_64.exe 7. Куліков П. М. Організаційно-економічні особливості функціонування системи освітнього кредитування в Україні / П. М. Куліков // Збірник наукових праць Національного університету державної податкової служби України. - № 1. $\quad$ 2009. - С. 167-174. 8. Лазарев В. А. Конкурентоспособность вуза как обьект управлення: [монографія] / В. А. Лазарев, С. А. Мохначев. - $\quad$ М. : Пригородные вести, 2003. - 374 с. 9. Пащенко Н. И. Конкурентоспособность вузов и стратегии их деятельности в условиях региональной конкуренции : дис. ... канд. экон. наук/Н. И. Пащенко. - Уфа, 1999. - 205 с. 10. Петруня Ю. Є. Маркетинг на ринку освітніх послуг / Ю. С. Петруня // Маркетинг в Україні. - $\quad$ 2004. - $\quad$ №1. - $\quad$ С. $23-27 \quad$ 11. Романова И. Б. Управление конкурентоспособностью высшего учебного заведения / И. Б. Романова. - Ульяновск : Средневолж. науч. центр, 2005. - 225 с. 12. Тарасенко І. О. Проблеми фінансування вищої освіти в Україні в контексті забезпечення конкурентоспроможності// I. О Тарасенко, Т. М. Нефедова. - Вісник КНУТД. - 2013. - № 4// [Електронний ресурс]. - Режим доступу: http://vistnyk.knutd.com.ua/files/Visnyk/Visnyk_ 3_2014.pdf 13. Фасхиев Х.А. Оценка конкурентного потенциала и конкурентоспрособности высшего учебного заведения / Х. А. Фасхиев, И. М. Гараев // [Електронний ресурс]. - Режим доступу: http//kampi.ru 14. Фатхутдинов Р. А. Управление конкурентоспособностью вуза / Р. А. Фатхутдинов // Высш. образование в России. - 2006. - № 9. - С. 37-38. 15. Шевченко Л. С. Фінансування вищої освіти: подолання загроз ресурсної залежності / Л. С. Шевченко // [Електронний ресурс]. - Режим доступу: http://www.rusnauka.com 